\title{
Comparison of nutritional values of pheasant and broiler chicken meats
}

\author{
Eva Straková1, Pavel Suchý1, Kateřina Karásková1, Márk Jámbor ${ }^{1}$, Petr Navrátil² \\ ${ }^{1}$ Department of Nutrition, Animal Husbandry and Animal Hygiene, Faculty of Veterinary Hygiene and Ecology \\ University of Veterinary and Pharmaceutical Science Brno, Czech Republic \\ ${ }^{2}$ SANO, s.r.o., Czech Republic
}

Received October 20, 2010

Accepted October 11, 2011

\begin{abstract}
The aim of this study was to compare the nutritional and dietetic values of the meat of chickens of the common pheasant (Phasianus colchicus L.) intensively fattened until 90 days of age to the meat of broiler chickens fattened until 40 days of age. Breast muscles in pheasants contained higher protein content on a dry matter basis (930.57 $\mathrm{g} \cdot \mathrm{kg}^{-1}$ in females, $937.23 \mathrm{~g} \cdot \mathrm{kg}^{-1}$ in males) and lower fat content (29.58 $\mathrm{g} \cdot \mathrm{kg}^{-1}$ in females, $29.92 \mathrm{~g} \cdot \mathrm{kg}^{-1}$ in males) as compared to thigh muscles (protein: $781.80 \mathrm{~g} \cdot \mathrm{kg}^{-1}$ in females, $810.07 \mathrm{~g} \cdot \mathrm{kg}^{-1}$ in males, fat: $163.74 \mathrm{~g} \cdot \mathrm{kg}^{-1}$ in females, $140.71 \mathrm{~g} \cdot \mathrm{kg}^{-1}$ in males). Breast muscles in both females and males contained less calcium $\left(0.67 \mathrm{~g} \cdot \mathrm{kg}^{-1}\right.$ in females, $0.57 \mathrm{~g} \cdot \mathrm{kg}^{-1}$ in males) and more phosphorus $\left(10.16 \mathrm{~g} \cdot \mathrm{kg}^{-1}\right.$ in females, $9.72 \mathrm{~g} \cdot \mathrm{kg}^{-1}$ in males) compared to the thigh muscles in which the mean calcium content was $1.28 \mathrm{~g} \cdot \mathrm{kg}^{-1}$ in females and $1.32 \mathrm{~g} \cdot \mathrm{kg}^{-1}$ in males, and the mean phosphorus content was $9.31 \mathrm{~g} \cdot \mathrm{kg}^{-1}$ in females and $9.23 \mathrm{~g} \cdot \mathrm{kg}^{-1}$ in males. Breast and thigh muscles in both female and male pheasants contained higher protein content and lower fat content compared to broiler meat. The calcium content in pheasant meat was lower whereas the phosphorus and magnesium contents were higher compared to broiler meat. Pheasant meat with high content of protein and low fat content is very valuable foodstuff and its dietetic value exceeds that of broiler meat. There is a lack of scientific literature on this subject which has not been studied in detail yet. This study extends the current scope of scientific knowledge in this field.
\end{abstract}

Common pheasant, broiler, breast and thigh muscles, chemical analysis

The present study compares the chemical composition of pheasant meat and broiler meat from fattened broiler chickens, and evaluates the dietetic value of both meats with regard to human nutrition. The chemical composition of meat is determined genetically, being also affected by major external factors such as the diet. This is confirmed by a study of Kokoszyński et al. (2008) who reported differences in the carcass value of pheasants reared at different levels of nutrition. There are differences between pheasants raised in captivity and wild pheasants not only in the carcass value but also in the chemical composition of muscles as reported by Saeki and Kumagai (1990). Tucak et al. (2008) found that the meat of wild pheasants contains more protein and less fat, thus having a higher biological value than the meat of artificially reared pheasants. Differences between breast and thigh muscles in pheasants are also discussed by Petkov (1984) who found based on the chemical analysis that breast muscles have a higher nutritional value than thigh muscles. The effect of sex on the carcass value in pheasants was investigated by Adamski and Kuzniacka (2006) who reported that pheasants can be slaughtered at the age of 16-20 weeks. Kuzniacka et al. (2007) reported that no significant differences were found between both sexes at this age in the protein content in breast muscles $(24.53$ and $25.19 \%)$ and of fat in thigh muscles (2.31 and 2.78\%). Večerek et al. (2005) found an increase in dry matter content in thigh muscles in pheasants on days 50 and 90 . They also found low fat content on days 40 and 90 of the fattening period. The chemical composition of partridge meat was studied by Gaglianone et al. (2006) who found that breast muscles in partridge are characterized by increased contents of protein, ash and phosphorus, and decreased contents

Phone: +420541562672

Fax: +420541562 675

E-mail: strakovae@vfu.cz

http://www.vfu.cz/acta-vet/actavet.htm 
of dry matter, fat and calcium. Thigh muscles are characterized by increased content of dry matter fat and calcium, and decreased content of protein, ash and phosphorus. Detailed knowledge is available on the chemical composition of muscles in broiler chickens. The chemical variables of muscles in meat hybrid broiler chickens were investigated by Suchý et al. (2002) who found that breast

Table 1. Component $(\mathrm{kg})$ and nutrient contents $\left(\mathrm{g} \cdot \mathrm{kg}^{-1}\right)$ in feed mixtures for broiler and pheasant chickens related to $100 \%$ dry matter

\begin{tabular}{|c|c|c|c|}
\hline Components & BR 1 & BR 2 & BR 3 \\
\hline Wheat & 41.70 & 47.80 & 47.20 \\
\hline Maize & 15.00 & 15.00 & 20.00 \\
\hline Soybean extracted meal & 35.80 & 29.60 & 24.90 \\
\hline Soybean oil & 3.00 & 3.60 & 4.60 \\
\hline Biolys 65 (lysine supplement) & 0.58 & 0.46 & 0.24 \\
\hline D,L-Methionine & 0.30 & 0.25 & 0.20 \\
\hline L-Threonine & 0.12 & 0.08 & 0.05 \\
\hline Monocalciumphosphate & 1.18 & 1.00 & 0.90 \\
\hline Feeding salt & 0.36 & 0.38 & 0.36 \\
\hline Ground lime stone & 1.76 & 1.63 & 1.35 \\
\hline Biofactor supplement* & 0.20 & 0.20 & 0.20 \\
\hline Nutrients & BR 1 & BR 2 & $\mathrm{BR} 3$ \\
\hline N substances & 258.4 & 245.9 & 245.9 \\
\hline Fat & 51.6 & 58.0 & 58.0 \\
\hline Fibre & 24.3 & 26.3 & 26.3 \\
\hline BNLV & 599.9 & 609.9 & 609.9 \\
\hline Starch & 411.7 & 415.0 & 415.0 \\
\hline Ash & 65.8 & 59.8 & 59.8 \\
\hline $\mathrm{Ca}$ & 11.18 & 9.95 & 9.95 \\
\hline $\mathrm{P}$ & 8.61 & 7.72 & 7.72 \\
\hline $\mathrm{Mg}$ & 2.72 & 2.74 & 2.74 \\
\hline $\operatorname{ME}\left(\mathrm{MJ} \cdot \mathrm{kg}^{-1}\right)$ & 12.9 & 13.3 & 13.3 \\
\hline GE $\left(\mathrm{MJ} \cdot \mathrm{kg}^{-1}\right)$ & 18.99 & 19.1 & 19.1 \\
\hline $\mathrm{NaCl}$ & 2.6 & 2.9 & 2.9 \\
\hline
\end{tabular}

BR 1 - feed for pheasant and broiler chickens until 15 days of age in the form of mash

BR 2 - granulated feed for pheasant and broiler chickens until 30 days of age

BR 3 - granulated feed for pheasant (until 90 Days of age) and broiler (until 40 days of age) chickens

*The premix of specifically active substances used by the producer contained: vitamin A 1600000 IU; vitamin D3 $500000 \mathrm{IU}$; alpha-tocopherol $10000 \mathrm{mg}$; vitamin K3 300 $\mathrm{mg}$; vitamin B1 $800 \mathrm{mg}$; vitamin B2 $1300 \mathrm{mg}$; vitamin B6 $600 \mathrm{mg}$; vitamin B12 $3 \mathrm{mg}$; biotin $30 \mathrm{mg}$; folic acid 500 $\mathrm{mg}$; niacinamide $6000 \mathrm{mg}$; calcium pantothenate $2500 \mathrm{mg}$; betaine $50000 \mathrm{mg}$; butylhydroxytoluene $3400 \mathrm{mg}$; propyl gallate $1200 \mathrm{mg}$; ethoxyquin $540 \mathrm{mg}$; ferrous sulphate monohydrate $10000 \mathrm{mg}$; manganese oxide $16000 \mathrm{mg}$; zinc oxide $16000 \mathrm{mg}$; copper sulphate $1700 \mathrm{mg}$; potassium iodide $200 \mathrm{mg}$; sodium selenite $30 \mathrm{mg}$; kobalt sulphate 50 mg; phytase 50000 FTU; glucanase 24000 BGU; xylanase 1 100000 EXU muscles contain higher contents of protein, ash and phosphorus and lower contents of dry matter, fat and calcium whereas thigh muscles have higher contents of dry matter, fat and calcium, and less protein, ash and phosphorus.

The aim of the study was to compare the nutritional value of meat from pheasants (Phasianus colchicus L.) intensively fattened until 90 days of age with the nutritional value of meat from broiler chickens fattened until 40 days of age (age of animals at slaughter).

\section{Materials and Methods}

The analysis was performed on breast and thigh muscles from a total of 80 pheasant chickens (40 females and 40 males) with the mean weight of $0.790 \pm 0.052 \mathrm{~kg}$ (females) and $1.023 \pm 0.058 \mathrm{~kg}$ (males), and from 60 hybrid ROSS 308 combination broiler chickens (30 females and 30 males) with the mean weight of $2.214 \pm 0.177 \mathrm{~kg}$ (females) and $2.595 \pm 0.195$ $\mathrm{kg}$ (males). Pheasant and broiler chickens were reared in aviaries on deep bedding in the accredited experimental enclosure with a controlled air-conditioning regimen. The fattening regimen complied with technological instructions for the fattening of ROSS 308 chickens. Animals received a feed mixture and water ad libitum for the whole period of fattening. During the fattening period, the following feed mixtures were administered to broiler and pheasant chickens: BR 1 complete feed mixture in mash form (days 1-15), BR2 granulated feed mixture (days 16-30) and BR 3 feed mixture (on days 31-40 to broiler chickens and on days 31-90 to pheasant chickens). The list of components and nutrients contained in the feed mixtures is in Table 1.

After slaughter (broiler chickens were slaughtered on Day 40, pheasant chickens were slaughtered on Day 90), breast and thigh muscles were dissected. After the homogenization of individual muscles from each animal, samples were collected for the determination of dry matter, protein $(\mathrm{N} \times 6.25)$, fat, ash, and elements such as calcium (Ca), phosphorus $(\mathrm{P})$, and magnesium $(\mathrm{Mg})$. Dry matter content was determined gravimetrically after the sample was dried at $103 \pm 2{ }^{\circ} \mathrm{C}$ to constant weight. Nitrogen was determined using 
the Büchi analyser (Centec automatika, spol. s.r.o.). Fat was determined using ANKOM ${ }^{\mathrm{XT10}}$ Fat Analyzer (O.K. SERVIS BioPro, Czech Republic). Ash was determined gravimetrically after incineration at $550{ }^{\circ} \mathrm{C}$. Calcium, phosphorus and magnesium were determined after incineration followed by extraction and titration. Every individual sample was analysed twice and the mean value of the two measurements was calculated. For precision and correct interpretation, the results of analyses were related to $100 \%$ dry matter. The results obtained were processed using the statistical programme Unistat CZ, version 5.6 for Excel (2005), with which the mean values and their differences were evaluated by multiple comparisons using the Turkey HSD test, at the following levels of significance: $P \leq 0.01$ and $P \leq 0.05$.

\section{Results}

The analyses confirmed that broiler and pheasant meats significantly differ in the nutrient content including both organic and inorganic substances (Tables 2 and 3).

Table 2. Differences in the nutritional composition of breast muscles in pheasant and broiler chickens $(\mathrm{x} \pm \mathrm{SD})$ related to dry matter content

\begin{tabular}{|c|c|c|c|c|c|c|c|}
\hline Females & $\mathrm{n}$ & Protein & Crude fat & Ash & $\mathrm{Ca}$ & $\mathrm{P}$ & $\mathrm{Mg}$ \\
\hline Pheasant & 40 & 930.57 & 29.58 & 45.61 & 0.67 & 10.16 & 1.56 \\
\hline$\left(\mathrm{g} \cdot \mathrm{kg}^{-1}\right)$ & & \pm 26.839 & \pm 24.507 & \pm 1.401 & \pm 0.166 & \pm 0.367 & \pm 0.202 \\
\hline Broiler & 30 & $884.92^{* *}$ & $66.82^{* *}$ & $47.72^{\text {** }}$ & $2.03^{* *}$ & $9.25^{* *}$ & 1.47 \\
\hline$\left(\mathrm{g} \cdot \mathrm{kg}^{-1}\right)$ & & \pm 21.733 & \pm 21.389 & \pm 2.351 & \pm 0.175 & \pm 0.482 & \pm 0.228 \\
\hline Males & $\mathrm{n}$ & Protein & Crude fat & Ash & $\mathrm{Ca}$ & $\mathrm{P}$ & $\mathrm{Mg}$ \\
\hline Pheasant & 40 & 937.23 & 29.9 & 45.78 & 0.57 & 9.72 & 1.51 \\
\hline$\left(\mathrm{g} \cdot \mathrm{kg}^{-1}\right)$ & & \pm 25.7322 & \pm 20.570 & \pm 1.243 & \pm 0.066 & \pm 0.370 & \pm 0.141 \\
\hline Broiler & 30 & $868.24^{* *}$ & $67.25^{* *}$ & $48.04^{* * *}$ & $2.15^{* *}$ & $9.51^{*}$ & 1.54 \\
\hline$\left(\mathrm{g} \cdot \mathrm{kg}^{-1}\right)$ & & \pm 25.925 & \pm 14.303 & \pm 1.087 & \pm 0.138 & \pm 0.358 & \pm 0.150 \\
\hline
\end{tabular}

$(* * P \leq 0.01, * P \leq 0.05)$.

The content of protein per dry matter content in pheasant meat in both male and female pheasants was significantly higher $(P \leq 0.01)$ compared to broiler meat (Table 2$)$. The protein content in breast muscles was $5.16 \%$ higher in female pheasants and $7.95 \%$ higher in male pheasants than in broiler chickens. By contrast, the fat content in pheasant muscles was significantly lower $(P \leq 0.01)$ than in broiler chickens, being $55.27 \%$ and $55.51 \%$ lower than in male and female broilers, respectively. The ash content in the dry matter of breast muscles from pheasant chickens was significantly $(P \leq 0.01)$ lower than in broiler chickens, being $4.42 \%$ and $4.70 \%$ lower than in male and female broilers, respectively. The lower ash content in pheasant breast muscles was also associated with significantly lower contents $(P \leq 0.01)$ of $\mathrm{Ca}$ that were $67.00 \%$ lower in females and $73.49 \%$ lower in males. By contrast, the $\mathrm{P}$ content in the dry matter of pheasant breast muscles was higher, namely by $9.84 \%$ in females $(P \leq 0.01)$ and $2.21 \%$ in males $(P \leq 0.05)$. Interesting differences were also found between breast and thigh muscles of broiler chickens. In the breast muscles of females and males, higher P content was found (Tables 2 and 3), which was probably related to different activity and chemical composition of these types of muscles (breast, thigh). No significant differences were found in the mean contents of $\mathrm{Mg}$ recalculated to dry matter content in breast muscles of pheasants.

Thigh muscles were subjected to the same analysis as breast muscles (Table 3). The results of dry matter content in thigh muscles of pheasant and broiler chickens were similar to those obtained for breast muscles. The protein content in thigh muscles of female and male pheasants was significantly $(P \leq 0.01)$ higher than in broiler chickens. The mean values of protein in female and male pheasants were $20.14 \%$ and $23.47 \%$ higher than in female and male broilers. Thigh muscles in pheasants contained significantly $(P \leq 0.01)$ less fat (on a dry matter basis), the fat content was lower by $45.84 \%$ in females 
and $46.37 \%$ in males. Compared to broiler chickens, thigh muscles contained significantly $(P \leq 0.01)$ higher ash content (on a dry matter basis), being $19.53 \%$ and $20.38 \%$ higher than in female and male broilers. Although the ash content in thigh muscles of pheasant chickens was higher, the mean contents of monitored elements showed similar trends as observed in breast muscles. Such trends were characterized by significantly higher $(P \leq 0.01) \mathrm{Ca}$ content, significantly lower $(P \leq 0.01) \mathrm{P}$ content and significantly $(P \leq 0.01)$ higher $\mathrm{Mg}$ content (on a dry matter basis).

Table 3. Differences in the nutritional composition of thigh muscles in pheasant and broiler chickens $(\mathrm{x} \pm \mathrm{SD})$ related to dry matter content

\begin{tabular}{llcccccc}
\hline Females & $\mathrm{n}$ & Protein & Crude fat & Ash & $\mathrm{Ca}$ & $\mathrm{P}$ & $\mathrm{Mg}$ \\
\hline Pheasant & 40 & 781.80 & 163.74 & 46.52 & 1.28 & 9.31 & 1.63 \\
$\left(\mathrm{~g} \cdot \mathrm{kg}^{-1}\right)$ & & \pm 53.853 & \pm 56.035 & \pm 3.537 & \pm 0.174 & \pm 0.648 & \pm 0.203 \\
Broiler & 30 & $650.75^{* *}$ & $302.34^{* *}$ & $38.92^{* *}$ & $1.67^{* *}$ & $7.24^{* *}$ & $1.13^{* * *}$ \\
$\left(\mathrm{~g} \cdot \mathrm{kg}^{-1}\right)$ & & \pm 42.516 & \pm 34.051 & \pm 2.681 & \pm 0.216 & \pm 0.378 & \pm 0.168 \\
\hline Males & $\mathrm{n}$ & Protein & Crude fat & Ash & $\mathrm{Ca}$ & $\mathrm{P}$ & $\mathrm{Mg}$ \\
\hline Pheasant & 40 & 810.07 & 140.71 & 48.97 & 1.32 & 9.23 & 1.56 \\
$\left(\mathrm{~g} \cdot \mathrm{kg}^{-1}\right)$ & & \pm 80.856 & \pm 84.808 & \pm 5.512 & \pm 0.172 & \pm 0.905 & \pm 0.243 \\
Broiler & 30 & $656.09^{* *}$ & $262.35^{* *}$ & $40.68^{* *}$ & $1.80^{* *}$ & $7.60^{* *}$ & $1.12^{* * *}$ \\
$\left(\mathrm{~g} \cdot \mathrm{kg}^{-1}\right)$ & & \pm 87.605 & \pm 35.697 & \pm 2.686 & \pm 0.110 & \pm 0.329 & \pm 0.144 \\
\hline
\end{tabular}

$(* * P \leq 0.01, * P \leq 0.05)$.

\section{Discussion}

It follows from the results that pheasant and broiler meat significantly differ in their nutritional values. Such differences are determined genetically and may also be influenced by the diet as reported by Kokoszyński et al. (2008). It is obvious that similar differences between pheasants and broiler chickens also exist in the chemical composition of breast and thigh muscles as documented by Petkov (1984) in pheasants, Gaglianone et al. (2006) in partridges, or by Suchý et al. (2002) in broiler chickens. Broiler chickens and pheasants differ to a large extent in the chemical composition of breast and thigh muscles. However, this finding is contrary to the results reported by Kuzniacka et al. (2007) who did not observe such differences. The most probable reason for this disagreement is the fact that the obtained values were related to the original weight of muscles rather than to dry matter content and were probably affected by different dry matter and water contents in breast and thigh muscles. In conclusion, pheasant meat with high protein content and low fat content is valuable foodstuff and its dietetic value exceeds that of broiler meat; breast muscles have a higher dietetic value than thigh muscles.

\section{Acknowledgement}

This study was funded by the grant IGA 88/2010/FVHE

\section{References}

Adamski M, Kuzniacka J 2006: The effect of age and sex on slaughter traits of pheasants (Phasianus colchicus L.). 3rd Conference of genetic and environmental possibilities of adjusting the slaughter value and meat quality of animals to consumers' requirements. SEP 07-08, Lublin Krasnobrod, Poland

Gaglianone Moro ME, Ariki J, De Souza PA, De Souza HBA, De Moraes VMB, Vargas FC 2006: Carcass income and chemical composition of the native partridge (Rhynchotus rufescens - Tinamiformes) meat. Cienc Rural 36: 258-262

Kokoszyński D, Bernacki Z, Korytkowska H 2008: The effect of adding whole wheat grain to feed mixture on slaughter yield and carcass composition in game pheasants. J Cent Eur Agric 9: 659-664 
Kuzniacka J, Adamski M, Bernacki Z 2007: Effect of age and sex of pheasants (Phasianus colchicus L.) on selected physical properties and chemical composition of meat. Ann Anim Sci 7: 45-53

Petkov R 1984: Chemical composition of pheasant meat. Vet Med Nauki 21: 106-110

Saeki K, Kumagai H 1990: Nutritional composition of tissues of wild and bred pheasants. J Food Hyg Soc Japan 31: $522-526$

Suchý P, Jelínek P, Straková E, Hucl J 2002: Chemical composition of muscles of hybrid broiler chickens during prolonged feeding. Czech J Anim Sci 47: 511-518

Tucak Z, Skrivanko M, Posavcevic S, Periskic M, Boskovic I, Jumic V 2008: The influence of keeping pheasants in captivity vs. nature on the biological value of meat and its use in human nutrition. Coll Antropol 32: 959-962

Večerek V, Suchý P, Straková E, Vitula F, Mikundová M 2005: Variation in the chemical composition of muscles in young pheasants during their growth. Arch Anim Breed 48: 290-298 